\title{
EFFECT OF POLYMERS AND SUBSURFACE IRRIGATION ON MAIZE PRODUCTIVITY (ZEA MAYS, L.) UNDER SANDY SOIL CONDITIONS IN BALOZA REGION, EGYPT
}

\author{
Shoman, Hosam A. \\ Agronomy Unit, Department of Plant Production, Desert Research \\ Center, El-Matareya, Cairo, Egypt \\ E-mail: dr_hosam_shoman@yahoo.com
}

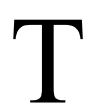

he field work was carried out at the Experimental Station of the Desert Research Center, Balosa region, North Sinai Governorate, during two summer seasons of 2015 and 2016. To study the effect of subsurface drip irrigation (SDI) at depths of 10, 20 and $30 \mathrm{~cm}$ below soil surface and polymers at the rates of $0,50,100$ and $150 \mathrm{~kg}$ polyacrylamide (PAM) per feddan ( 0.42 hectar) on productivity of maize under sandy soil conditions. Results indicated that all studied parameters [plant height $(\mathrm{cm})$, number of ears/plant, ear length $(\mathrm{cm})$, ear diameter $(\mathrm{cm})$, grains weight/ear, 1000-grain weight (g), harvest index (\%), shelling (\%), water use efficiency grain yield ( $\mathrm{kg} /$ feddan), total biomass ( $\mathrm{kg} /$ feddan), as well as, protein and oil (\%) in grains] were significantly affected by subsurface drip irrigation in both seasons. The highest values of these parameters were recorded when subsurface irrigation was used at a depth of $30 \mathrm{~cm}$ below the soil surface, followed by $20 \mathrm{~cm}$, while the minimum values were recorded for subsurface irrigation at a depth of $10 \mathrm{~cm}$ below the soil surface in 2015 and 2016 growing seasons. Increasing PAM rates from 0 to $150 \mathrm{~kg}$ /feddan caused a significant increase in all studied parameters of maize plants in the both seasons. The highest values of these parameters were obtained at $100 \mathrm{~kg}$ PAM/feddan compared with control treatment (without PAM). This has occurred in both seasons and in all parameters, except plant height, ear diameter, water use efficiency, protein $\%$ and oil $\%$, which were higher when using $150 \mathrm{~kg}$ PAM/feddan, but the differences between the two levels were insignificant in both seasons. Available data revealed that all studied parameters of maize were affected significantly by the interaction between subsurface drip irrigation and polymers in both seasons, except no. of ears/ plant, ear diameter and ear length, which did not reach a significant level in the two seasons. Maximum values of the interaction between subsurface drip irrigation and 
polymers were obtained when subsurface irrigation was used at a depth of $30 \mathrm{~cm}$ below the soil surface with the rate of polyacrylamide (100 kg/feddan) in two seasons under sandy soil conditions.

Keywords: maize, polyacrylamide, subsurface irrigation and yield components.

In Egypt, the total cropped area occupied by maize was 2.37 million feddan $(0.42$ hectar) with total production of 6.3 million ton (FAO, 2016). It is very important to increase production of maize to cover the gap between production and consumption. The development of non-traditional new technologies to conserve water is becoming important for attaining a sustainable economic growth, especially in agricultural countries. The subsurface irrigation system is a non-conventional method of irrigation, which corresponds with the water crisis that is worsening day by day. Thus, the use of this technique in the sandy soils leads to rationalize the water consumption of plants by up to $50 \%$ as a result of reducing the water lost from the soil either down by percolation or up by evaporation (Shahid et al., 2012). Improving the efficiency of irrigation water by different methods is one of the economically viable alternatives in overcoming the water scarcity. Sandy soils productivity can be improved when water is wisely managed by applying subsurface water retention technology that is regarded as apromising solution to sandy soils problems (Ismail and Ozawa, 2007). This is not only crucial for the sustainable agricultural yield but also to meet the challenges of current environmental issues and justice, financial problems and physical barriers (Ahmed et al., 2012). Many researchers have observed positive response of maize plants to subsurface irrigation and increasing yield and its components (Vories et al., 2009; Douh and Boujelben, 2011 and Robiul et al., 2011).

Polymers (polyacrylamide) is a water retaining, cross-linked hydrophilic, biodegradable amorphous polymer, which can absorb and retain water at least 300 times of its original weight and make at least 95 percent of stored water available for crop absorption (Johnson and Veltkamp 1985). When polymer is mixed with the soil, it forms an amorphous gelatinous mass on hydration and is capable of absorption and desorption over long period of time, hence acts as a slow release source of water in soil. These particles may be taken as "miniature water reservoir" in the soil and water will be removed from these reservoirs upon the root demand through osmotic pressure difference. Islam et al. (2011) reported that incorporating polymer into the soil will improve soil structure and water retention, thus reducing leaching, reducing water losses due to percolation and evaporation, protecting the plant against water stress and increasing both the nutrient and water supply to the roots. In addition, the structural improvement in soil will

Egyptian J. Desert Res., 67, No. 2, 291-304 (2017) 
lead to better aeration for the root system and reduces soil compaction. Many researchers found that polymers increased yield and its components of maize as recorded by Azzam (1983), El-Hady (1987), Huttermann et al. (1999), Yazdani et al. (2007) and Adem et al. (2016).

This study was designed to improve the maize productivity and increases water use efficiency at sandy soils as a result of reducing the water lost from the soil either down by percolation or up by evaporation by using some water retention technologies, i.e. subsurface irrigation at different depths and rates of polymers application under sandy soil conditions in Baloza region, Egypt.

\section{MATERIALS AND METHODS}

Two field experiments were carried out at Baloza Station of the Desert Research Center, North Sinai Governorate during two consecutive seasons of 2015 and 2016. The experiments aimed to study the effect of subsurface drip irrigation (SDI) and polymers (polyacrylamide, PAM) on productivity of maize plants cv. Giza 321 under sandy soil conditions. Twelve treatments were resulted from the combination of three depths of subsurface irrigation, where percolation lines were buried to a depth of 10,20 and $30 \mathrm{~cm}$ and four rates of polymers (PAM) as a soil conditioner, i.e. 0, 50, 100 and 150 $\mathrm{kg} /$ feddan, which were added at the depths of subsurface irrigation and mixed with fertilizers. The physical and chemical soil characteristics of the studied site were determined according to Klute (1986), as recorded in table (1). The chemical analysis of irrigation water was carried out using the standard method of Page et al. (1982) and presented in table (2).

Table (1). Physical and chemical properties of the experimental soil.

\begin{tabular}{|c|c|c|c|c|c|c|c|c|c|c|c|c|c|c|}
\hline \multicolumn{3}{|c|}{$\begin{array}{c}\text { Particle size } \\
\text { distribution }(\%)\end{array}$} & \multirow[t]{2}{*}{$\begin{array}{c}\text { Soil } \\
\text { texture }\end{array}$} & \multirow[t]{2}{*}{$\begin{array}{c}\text { Ec } \\
\left(\mathrm{dsm}^{-1}\right)\end{array}$} & \multirow[t]{2}{*}{ pH } & \multicolumn{5}{|c|}{ Available nutrients (cations) } & \multicolumn{4}{|c|}{ Available nutrients (anions) } \\
\hline Sand & Silt & Clay & & & & $\begin{array}{c}\mathbf{P} \\
(\%)\end{array}$ & $\begin{array}{c}\mathbf{K}^{+} \\
(\%)\end{array}$ & $\begin{array}{l}\mathrm{Na}^{+} \\
(\%)\end{array}$ & $\begin{array}{l}\mathrm{Ca}^{++} \\
(\mathrm{me} / \mathrm{l})\end{array}$ & $\begin{array}{l}\mathrm{Mg}^{++} \\
(\mathrm{me} / \mathrm{l})\end{array}$ & $\mathrm{Co}_{3}=$ & $\begin{array}{c}\mathrm{HCO}_{3}{ }^{-} \\
(\mathrm{me} / \mathrm{l})\end{array}$ & $\begin{array}{c}\mathrm{Cl}^{-} \\
(\mathrm{me} / \mathrm{l})\end{array}$ & $\begin{array}{l}\mathrm{SO}_{4}{ }^{=} \\
(\mathrm{me} / \mathrm{l})\end{array}$ \\
\hline 91.0 & 5.0 & 4.0 & sand & 1.29 & 8.0 & 0.39 & 0.51 & 4.54 & 3.42 & 4.11 & - & 3.62 & 3.00 & 5.80 \\
\hline
\end{tabular}

Table (2). Chemical analysis of irrigation water.

\begin{tabular}{ccccccccccccc}
\hline \multirow{2}{*}{ Samples } & $\mathbf{p H}$ & $\begin{array}{c}\text { E.C. } \\
\text { (ppm) }\end{array}$ & S.A.R. & & $\mathbf{C a}^{++}$ & $\mathbf{M g}^{++}$ & $\mathbf{N a}^{+}$ & $\mathbf{K}^{+}$ & $\mathbf{C O}_{3}{ }^{*}$ & $\mathbf{H C O}_{3-}$ & $\mathbf{S O}_{\mathbf{4}}{ }^{*}$ & $\mathbf{C l}^{-}$ \\
\hline $\begin{array}{c}\mathbf{2 0 1 5} \\
\text { season }\end{array}$ & 7.63 & 1411 & 3.55 & 3.41 & 3.12 & 8.47 & 0.63 & 0.17 & 3.22 & 2.38 & 7.47 \\
\hline $\begin{array}{c}\mathbf{2 0 1 6} \\
\text { season }\end{array}$ & 7.74 & 1355 & 3.18 & 3.54 & 3.25 & 7.36 & 0.58 & 0.32 & 3.68 & 2.79 & 8.24 \\
\hline
\end{tabular}

Egyptian J. Desert Res., 67, No. 2, 291-304 (2017) 
Organic manure was added at the rate of $15 \mathrm{~m}^{3} /$ feddan. While, calcium super-phosphate $\left(15.5 \% \quad \mathrm{P}_{2} \mathrm{O}_{5}\right)$ at the rate of $150 \mathrm{~kg} /$ feddan, potassium sulphate $\left(48 \% \mathrm{~K}_{2} \mathrm{O}\right)$ at the rate of $100 \mathrm{~kg} /$ feddan and nitrogen fertilizer was added as ammonium sulphate $(20.5 \% \mathrm{~N})$ at the rate of $150 \mathrm{~kg} \mathrm{~N} /$ feddan. Maize was planted in $1^{\text {st }}$ May in both growing seasons. All agricultural practices for maize crop production were followed according to the recommendation of Egyptian Ministry of Agriculture throughout the two experimental seasons.

At harvest, samples of 5 plants/ plot were taken randomly 121 and 126 days after sowing in 2015 and 2016 growing seasons, respectively, from the middle of plot for every treatments to determine the following characters: plant height $(\mathrm{cm})$, number of ears/plant, ear length $(\mathrm{cm})$, ear diameter $(\mathrm{cm})$, grains weight/ear, 1000-grain weight (g), harvest index (\%), shelling (\%), water use efficiency, grain yield $(\mathrm{kg} /$ feddan), total biomass $(\mathrm{kg} /$ feddan), as well as, protein and oil (\%) in grains, at harvest grain and total biomass $(\mathrm{kg})$ of each plot were recorded.

Whereas, shelling percentage (\%) was worked out by using the formula as suggested by Beadle (1987), shelling percentage (\%) was calculated according the following formula $=$ weight of grains from ten ears / weight ten ears $\mathrm{x} 100$. Water use efficiency (WUE) was calculated by dividing the crop yield $(\mathrm{kg})$ by the amount of water used $\left(\mathrm{m}^{3}\right)$ according to Molden et al. (2003). Harvest index (\%) was computed by using the following formula (Beadle, 1987): HI (\%) = grain yield/ total biomass x 100 .

A split plot design with three replicates was used. Main plots were occupied with subsurface irrigation and the sub plots allotted with polymer. Each experimental unit area was $10.5 \mathrm{~m}^{2}$ (1/400 feddan) in the two seasons. All recommended common agricultural practices were adopted throughout the two experimental seasons. All the obtained data for subsurface irrigation and PAM treatments were subjected to analysis of variance according to the method described by Gomez and Gomez (1984). Means comparison were done using least significant difference (LSD) at 5\% level of probability.

\section{RESULTS AND DISCUSSION}

\section{Effect of Subsurface Drip Irrigation, SDI}

Data in table (3) reveal that all studied parameters, i.e. plant height, number of ears/plant, ear diameter, ear length, grains weight/ ear, 1000-grain weight, shelling \%, grain yield, total biomass, harvest index, crop index, water use efficiency, protein $\%$ and oil $\%$, were significantly affected by subsurface drip irrigation in both seasons. The highest values of these characters were recorded when subsurface irrigation was at a depth of $30 \mathrm{~cm}$ below the soil surface, followed by $20 \mathrm{~cm}$, while the minimum values were recorded for subsurface irrigation at a depth of $10 \mathrm{~cm}$ below the soil surface in both 2015 and 2016 growing seasons.

Egyptian J. Desert Res., 67, No. 2, 291-304 (2017) 


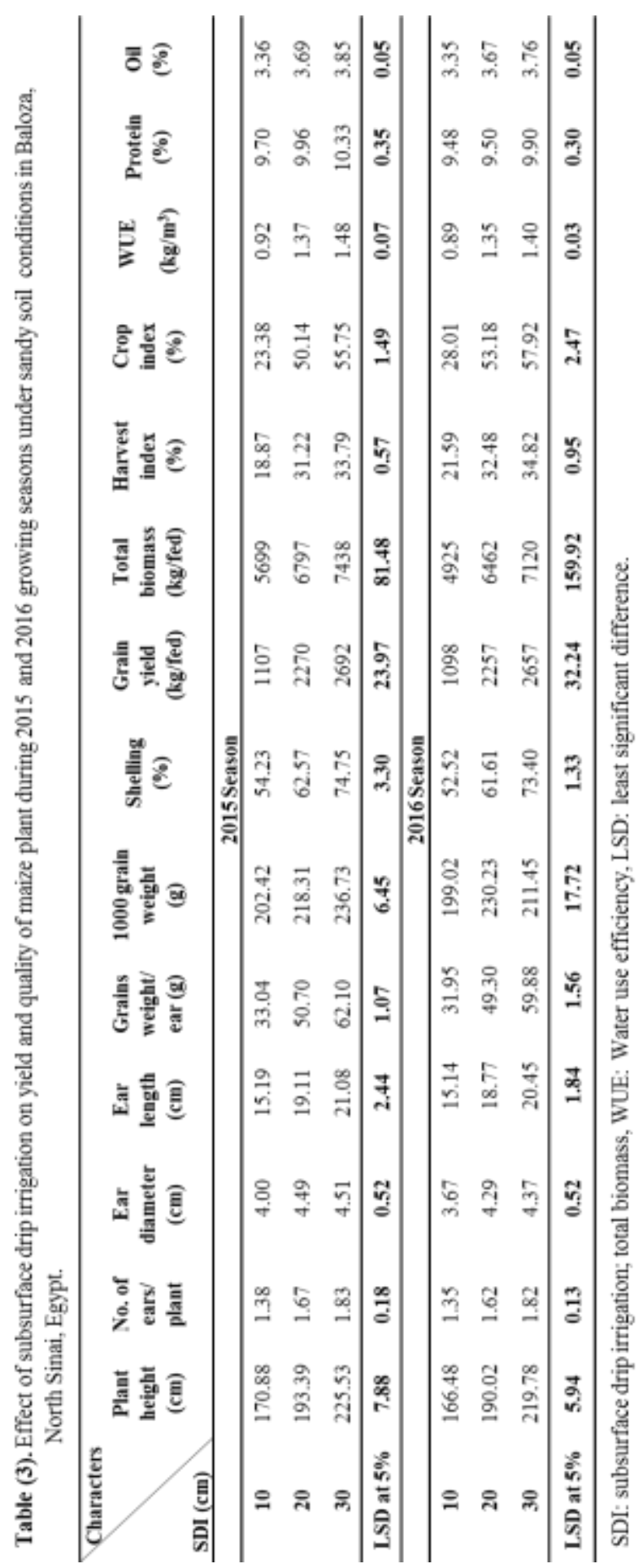

Egyptian J. Desert Res., 67, No. 2, 291-304 (2017) 
It is worthy to mention that the differences among the studied depths of subsurface irrigation in all studied characters may be due to that subsurface drip irrigation allows uniform delivery of water directly to the plant root zone, minimizes evaporative loss, improvs vegetative growth and yield characters and increases use efficiency over other irrigation methods. These results are further evidence that drip line depth at a $30 \mathrm{~cm}$ is probably acceptable on this soil type and climate for maize production. These results are in accordance with those mentioned by Lamm and Trooien (2003) and (2005), Douh and Boujelben (2011), Albasha et al. (2015) and Lamm et al. (2017).

\section{Effect of Polyacrylamide, PAM}

Data in table (4) indicate that increasing PAM rates from 0 to $150 \mathrm{~kg}$ /feddan caused a significant increase in all studied parameters of maize plants in both seasons. The highest values of these parameters were obtained at $100 \mathrm{~kg} \mathrm{PAM} /$ feddan compared with control treatment (without PAM). This is fairly true in both seasons and in all parameters, except plant height, ear diameter, water use efficiency, protein $\%$ and oil $\%$, which were higher when using $150 \mathrm{~kg}$ PAM/ feddan, but the differences between the two levels were insignificant in both seasons.

The increasing percentages of these attributes with using the rate of PAM (100 kg/feddan) comparing with control treatment were 38.92 and 41.78 for plant height, 16.56 and 17.69 for number of ears/plant, 40.06 and 30.56 for ear diameter, 63.72 and 65.88 for ear length, 237.02 and 248.86 for grains weight/ ear, 60.42 and 64.68 for 1000 -grain weight, 39.76 and 43.33 for shelling \%, 287.27 and 286.31 for grain yield, 67.18 and 62.22 for total biomass, 127.67 and 133.84 for harvest index, 222.57 and 230.28 for crop index, 85.19 and 92.21 for water use efficiency, 14.84 and 13.19 for protein $\%$ and 9.09 and 13.07 for oil \% in 2015 and 2016 seasons, respectively. The increasing in the values of these traits under this study resulted from the incorporation of polymers material with soil, can retain large quantities of water, nutrients, which are released slowly as required by the plant to improve growth under limited water supply. This may also be due to developments in the nature of root growth, like root length, root volume, rootfresh and dry weight which in turn lead to better translocation of water, nutrients and photoassimilates and finally better plant development. Similar results of incorporating polymer into the soil and its effect on the yield and its components have been reported by Sivapalan (2006), Sarvas et al. (2007), Yazdani et al. (2007), Islam et al. (2011), Rafiei et al. (2013), Adem et al. (2016) and Kumari et al. (2017).

Egyptian J. Desert Res., 67, No. 2, 291-304 (2017) 


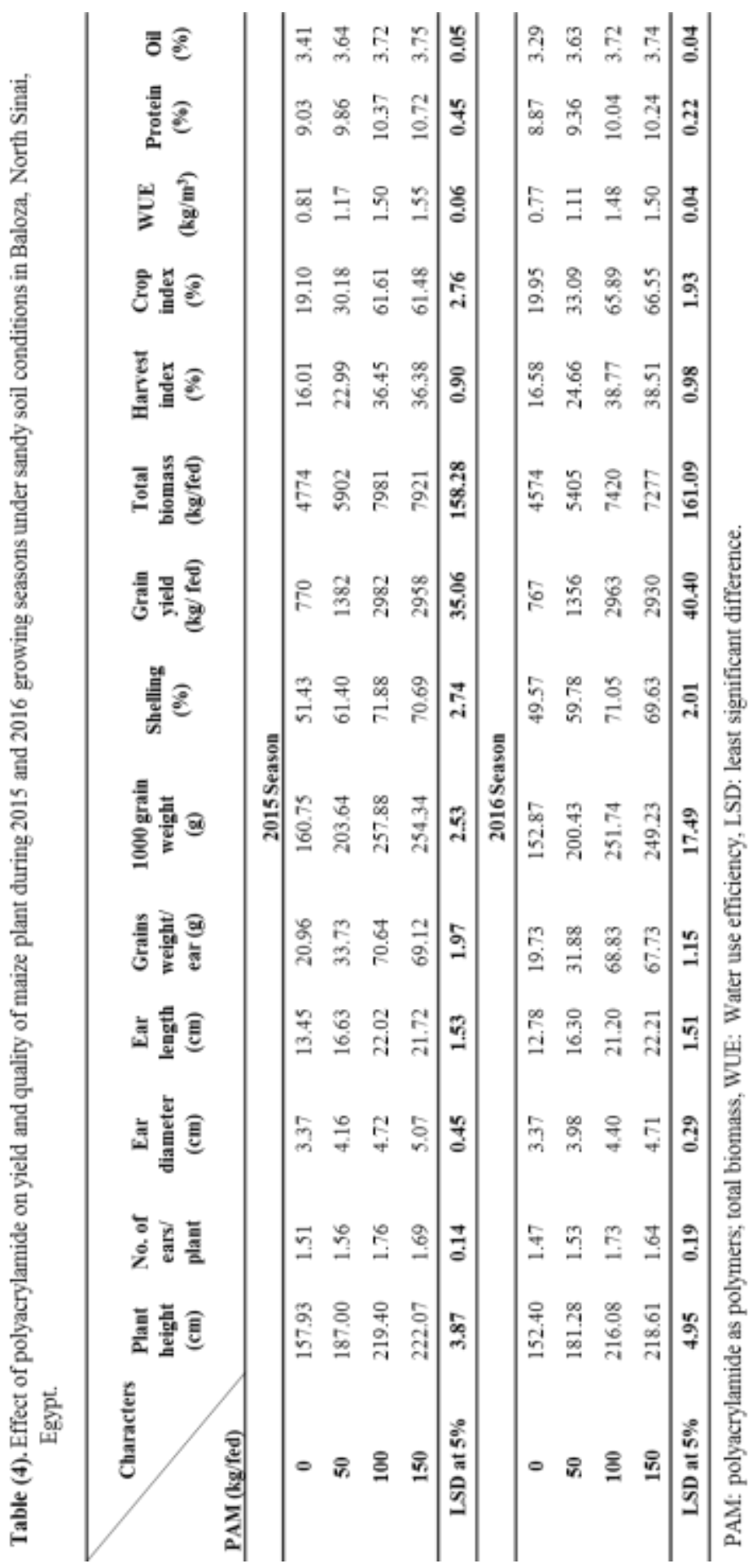

Egyptian J. Desert Res., 67, No. 2, 291-304 (2017) 


\section{Effect of the Interaction between Subsurface Drip Irrigation and Polymers, SDI x PAM}

Available data in table (5 and 6) show that all studied parameters of maize were affected significantly by the interaction between subsurface drip irrigation and polymers in both seasons, except number of ears/plant, ear diameter and ear lenght don't reach to significant level in the two seasons. The highest values for each of plant height were 253.90 and $250.97 \mathrm{~cm}$, grain weight were 93.83 and $91.45 \mathrm{~g}, 1000$-grain weight were 269.05 and $263.07 \mathrm{~g}$, shelling were 82.78 and $81.69 \%$, grain yield were 4028 and 3972 $\mathrm{kg} /$ feddan, total biomass were 8938 and $8743 \mathrm{~kg} /$ feddan, harvest index were 45.06 and $44.43 \%$, crop index were 82.03 and $83.50 \%$, WUE were 1.82 and $1.74 \mathrm{~kg} \mathrm{~m}^{3}$, protein were 11.09 and $16.65 \%$ and oil were 3.92 and $3.89 \%$, due to the interaction between subsurface drip irrigation and polymers were obtained when subsurface irrigation was used at a depth of $30 \mathrm{~cm}$ below the soil surface, with the rate of $100 \mathrm{~kg}$ polyacrylamide/feddan, in the first and seconed season, respectively. Regarding of subsurface drip irrigation, Ahmed et al. (2012) reported that subsurface drip irrigation allows highly production of crops without negative environmental impacts associated with leaching or runoff. Lamm et al. (2017) found that the highest values of yield components of maize and water use efficiency were observed under subsurface drip system, which was approximately twice and seven times than sprinkler and basin systems, respectively, for many crops production under desert condition. However, about of PAM, Adem et al., (2016) pointed out that using of polymwers as afertilizer with maize led to an increase in ear weight, 1000-grains weight, grain yield and total biomass and also increased water use efficiency in percentages ranging from 33-87\%.

\section{CONCLUSION}

The results indicate that the use of subsurface drip irrigation at a depth of $30 \mathrm{~cm}$ below the soil surface in combination with addition of $100 \mathrm{~kg}$ polyacrylamide /feddan had a significant effect on most of the parametrs under study. This may be due to the integration between the study factors to benefit each other, so that the water provided by subsurface irrigation don't lost quickly away of the plant, but is caught on the surface of the polysaccharides granules, so that the plant can absorb it by roots, thus reducing the amount of irrigation water needed for the unit area and improving its productivity.

Egyptian J. Desert Res., 67, No. 2, 291-304 (2017) 
Table (5). Effect of the interaction between subsurface drip irrigation and polyacrylamide on yield and quality of maize during 2015 and 2016 growing seasons under sandy soil conditions in Baloza, North Sinai, Egypt.

\begin{tabular}{|c|c|c|c|c|c|c|c|c|}
\hline 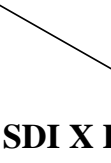 & laracters & $\begin{array}{c}\text { Plant } \\
\text { height } \\
\text { (cm) }\end{array}$ & $\begin{array}{l}\text { No. of ears/ } \\
\text { plant }\end{array}$ & $\begin{array}{c}\text { Ear } \\
\text { diameter } \\
(\mathbf{c m})\end{array}$ & $\begin{array}{c}\text { Ear } \\
\text { length } \\
(\mathrm{cm})\end{array}$ & $\begin{array}{l}\text { Grains } \\
\text { weight/ } \\
\text { ear (g) }\end{array}$ & $\begin{array}{l}1000 \text { grain } \\
\text { weight } \\
\text { (g) }\end{array}$ & $\begin{array}{c}\text { Shelling } \\
(\%)\end{array}$ \\
\hline $\begin{array}{l}\text { SDI } \\
(\mathbf{c m})\end{array}$ & $\begin{array}{c}\text { PAM } \\
(\mathrm{kg} / \mathrm{fed})\end{array}$ & \multicolumn{7}{|c|}{2015 Season } \\
\hline \multirow{4}{*}{10} & 0 & 149.97 & 1.33 & 3.11 & 11.23 & 18.28 & 138.04 & 41.78 \\
\hline & 50 & 161.47 & 1.33 & 4.11 & 14.20 & 28.37 & 181.61 & 53.34 \\
\hline & 100 & 185.30 & 1.47 & 4.25 & 18.67 & 43.51 & 246.27 & 61.17 \\
\hline & 150 & 186.77 & 1.40 & 4.51 & 16.65 & 42.01 & 243.77 & 60.60 \\
\hline \multirow{4}{*}{20} & $\mathbf{0}$ & 156.20 & 1.47 & 3.90 & 13.59 & 21.03 & 154.51 & 49.46 \\
\hline & 50 & 169.93 & 1.53 & 4.20 & 16.55 & 33.43 & 207.34 & 59.28 \\
\hline & 100 & 221.90 & 1.87 & 4.62 & 22.79 & 74.59 & 258.32 & 71.67 \\
\hline & 150 & 225.53 & 1.80 & 5.24 & 23.50 & 73.74 & 253.05 & 69.88 \\
\hline \multirow{4}{*}{30} & $\mathbf{0}$ & 167.63 & 1.73 & 3.10 & 15.55 & 23.57 & 189.69 & 63.06 \\
\hline & 50 & 229.60 & 1.80 & 4.17 & 19.15 & 39.39 & 221.98 & 71.58 \\
\hline & 100 & 253.90 & 1.93 & 5.30 & 24.61 & 93.83 & 269.05 & 82.78 \\
\hline & 150 & 251.00 & 1.87 & 5.45 & 25.01 & 91.61 & 266.19 & 81.59 \\
\hline \multicolumn{2}{|c|}{ LSD at 5\% } & 6.70 & NS & NS & NS & 1.42 & 2.39 & 1.12 \\
\hline & & \multicolumn{7}{|c|}{ 2016 Season } \\
\hline \multirow{4}{*}{10} & $\mathbf{0}$ & 146.20 & 1.27 & 2.80 & 10.76 & 17.35 & 134.50 & 40.32 \\
\hline & 50 & 156.73 & 1.33 & 3.80 & 13.70 & 26.77 & 180.48 & 50.18 \\
\hline & 100 & 180.30 & 1.40 & 3.90 & 17.92 & 42.78 & 241.57 & 60.16 \\
\hline & 150 & 182.67 & 1.40 & 4.19 & 18.17 & 40.88 & 239.54 & 59.43 \\
\hline \multirow{4}{*}{20} & $\mathbf{0}$ & 152.77 & 1.40 & 3.97 & 13.59 & 20.72 & 217.59 & 48.67 \\
\hline & 50 & 165.93 & 1.47 & 4.11 & 15.47 & 32.12 & 203.53 & 56.58 \\
\hline & 100 & 219.17 & 1.87 & 4.27 & 22.37 & 72.25 & 250.57 & 71.31 \\
\hline & 150 & 222.20 & 1.73 & 4.81 & 23.66 & 72.11 & 249.23 & 69.87 \\
\hline \multirow{4}{*}{30} & 0 & 158.23 & 1.73 & 3.34 & 13.99 & 21.12 & 106.52 & 59.71 \\
\hline & 50 & 221.17 & 1.80 & 4.02 & 19.71 & 36.75 & 217.27 & 72.58 \\
\hline & 100 & 250.97 & 1.93 & 5.02 & 23.30 & 91.45 & 263.07 & 81.69 \\
\hline & 150 & 248.77 & 1.80 & 5.12 & 24.79 & 90.20 & 258.93 & 79.59 \\
\hline \multicolumn{2}{|c|}{ LSD at 5\% } & 8.58 & NS & NS & NS & 0.99 & 3.29 & 0.68 \\
\hline
\end{tabular}


Table (6). Effect of the interaction between subsurface drip irrigation and polyacrylamide on yield and quality of maize during 2015 and 2016 growing seasons under sandy soil conditions in Baloza, North Sinai, Egypt.

\begin{tabular}{|c|c|c|c|c|c|c|c|c|}
\hline \multicolumn{2}{|c|}{ SDI X PAM } & $\begin{array}{c}\text { Grain } \\
\text { yield } \\
(\mathrm{kg} / \mathrm{fed})\end{array}$ & $\begin{array}{c}\text { Total } \\
\text { biomass } \\
\text { (kg/fed) }\end{array}$ & $\begin{array}{c}\text { Harvest } \\
\text { index } \\
(\%)\end{array}$ & $\begin{array}{c}\text { Crop } \\
\text { index } \\
(\%)\end{array}$ & $\begin{array}{c}\text { WUE } \\
\left(\mathrm{kg} / \mathrm{m}^{3}\right)\end{array}$ & $\begin{array}{c}\text { Protein } \\
(\%)\end{array}$ & $\begin{array}{l}\text { Oil } \\
(\%)\end{array}$ \\
\hline $\begin{array}{l}\text { SDI } \\
(\mathbf{c m})\end{array}$ & $\begin{array}{c}\text { PAM } \\
\text { (kg/fed) }\end{array}$ & \multicolumn{7}{|c|}{2015 Season } \\
\hline \multirow{4}{*}{10} & $\mathbf{0}$ & 587 & 3904 & 15.04 & 17.72 & 0.68 & 8.73 & 3.21 \\
\hline & 50 & 893 & 4863 & 18.40 & 22.57 & 0.90 & 9.74 & 3.37 \\
\hline & 100 & 1492 & 7069 & 21.11 & 26.76 & 0.98 & 10.11 & 3.40 \\
\hline & 150 & 1456 & 6959 & 20.93 & 26.48 & 1.10 & 10.22 & 3.46 \\
\hline \multirow{4}{*}{20} & $\mathbf{0}$ & 779 & 5083 & 15.33 & 18.10 & 0.82 & 9.10 & 3.28 \\
\hline & 50 & 1429 & 6211 & 23.05 & 29.99 & 1.22 & 9.75 & 3.74 \\
\hline & 100 & 3427 & 7937 & 43.18 & 76.03 & 1.71 & 10.14 & 3.85 \\
\hline & 150 & 3446 & 7957 & 43.31 & 76.42 & 1.72 & 10.83 & 3.87 \\
\hline \multirow{4}{*}{30} & $\mathbf{0}$ & 943 & 5335 & 17.68 & 21.48 & 0.93 & 9.25 & 3.74 \\
\hline & $\mathbf{5 0}$ & 1822 & 6631 & 27.50 & 37.97 & 1.38 & 10.10 & 3.71 \\
\hline & 100 & 4028 & 8938 & 45.06 & 82.03 & 1.82 & 11.09 & 3.92 \\
\hline & 150 & 3973 & 8335 & 43.91 & 79.52 & 1.76 & 10.74 & 3.80 \\
\hline \multicolumn{2}{|c|}{ LSD at 5\% } & 20.34 & 174.14 & 1.05 & 1.78 & 0.05 & 0.26 & 0.09 \\
\hline & & \multicolumn{7}{|c|}{ 2016 Season } \\
\hline \multirow{4}{*}{10} & $\mathbf{0}$ & 569 & 3860 & 14.74 & 17.29 & 0.66 & 8.64 & 3.21 \\
\hline & 50 & 886 & 4505 & 19.72 & 24.59 & 0.88 & 9.53 & 3.37 \\
\hline & 100 & 1486 & 5781 & 25.72 & 34.62 & 0.99 & 9.80 & 3.40 \\
\hline & 150 & 1450 & 5553 & 26.18 & 35.53 & 1.02 & 9.96 & 3.44 \\
\hline \multirow{4}{*}{20} & $\mathbf{0}$ & 754 & 4774 & 15.81 & 18.78 & 0.80 & 8.93 & 3.28 \\
\hline & 50 & 1426 & 5679 & 25.11 & 33.55 & 1.16 & 9.03 & 3.69 \\
\hline & 100 & 3432 & 7735 & 44.37 & 79.78 & 1.71 & 9.94 & 3.85 \\
\hline & 150 & 3417 & 7661 & 44.62 & 80.61 & 1.73 & 10.12 & 3.87 \\
\hline \multirow{4}{*}{30} & $\mathbf{0}$ & 977 & 5089 & 19.21 & 23.78 & 0.85 & 9.03 & 3.38 \\
\hline & 50 & 1756 & 6030 & 29.14 & 41.14 & 1.28 & 9.52 & 3.82 \\
\hline & 100 & 3972 & 8743 & 44.43 & 83.50 & 1.74 & 10.65 & 3.89 \\
\hline & 150 & 3922 & 8619 & 43.50 & 81.26 & 1.68 & 10.41 & 3.77 \\
\hline \multicolumn{2}{|c|}{ LSD at $5 \%$} & 25.63 & 119.02 & 1.70 & 1.33 & 0.06 & 0.18 & 0.08 \\
\hline
\end{tabular}

Egyptian J. Desert Res., 67, No. 2, 291-304 (2017) 


\section{REFERENCES}

Adem, G., K. Nurgul, T. Metin, E. Erdal, Y. Ertan and A. Nazmiye (2016). Evaluation of effects of water-saving superabsorbent polymer on corn (Zea mays L.) yield and phosphorus fertilizer efficiency. Turk. J. Agric., 40: 365-378.

Ahmed, T.F., H.N. Hashmi, A.R. Ghumman and A.A. Sheikh (2012). Performance assessment of surface and subsurface drip irrigation system for date palm fruit trees. African Journal of Agricultural Research, 7 (10): 1542-1549.

Albasha, R., C. Dejean, J.C. Mailhol, J.J. Weber, C. Bollègue and J.M. Lopez (2015). Performance of subsurface drip irrigation for maize under Mediteranean and temperate Oceanic climate conditions. $26^{\text {th }}$ Euro-Mediterranean Regional Conference and Workshops «Innovate to improve Irrigation performances».

Azzam, R. (1983). Polymeric conditioner gels for desert soils. Communications in Soil Science and Plant Analysis, 14: 739-760.

Beadle, C.L. (1987). In "Plant Growth Analysis". Techniques in Bioproductivity and Photosynthesis. Second Edition. (Coombs, J., D.O. Hall, S.P. Long and J.M.O. Sacrlock Eds.). Pregamon Press. Oxford New York, USA, pp. 21-23.

Douh, B. and A. Boujelben (2011). Effects of surface and subsurface drip irrigation on agronomic parameters of maize (Zea mays L.) under Tunisian climatic condition. J. Nat. Prod. Plant Resour., 1 (3): 8-14.

El-Hady, O.A. (1987). Hydrogels for increasing water and fertilizers use efficiency in sandy soils. First Conference on "Fertilizers availability and needs" S.W.R.I., A.R.C.; Ministry of Agric., Egypt, pp. 478496.

FAO (2016). Food and Agricultural Organization. Available online: www.fao.org.

Gomez, K.A. and A.A. Gomez (1984). In "Statistical Procedures in Agricultural Research. Second Edition. New York, Chichester, Wiley Paperback, $680 \mathrm{p}$.

Huttermann, A., L.J. Orikiriza and H. Agapa (2009). Application of superabsorbent polymers for improving the ecological chemistry of degraded or polluted lands. Clean-Soil, Air, Water, 37 (7): 517-526.

Islam, M.R., H.Y. Mao, P. Jia, A.E. Eneji and X. Xue (2011). Effects of water-saving superabsorbent polymer on antioxidant enzyme activities and lipid peroxidation in corn (Zea mays L.) under drought stress. J. Sci. Food Agric., 21: 215-223.

Ismail, S.M. and K. Ozawa (2007). Improvement of crop yield, soil moisture distribution and water use efficiency in sandy soils by clay application. Applied Clay Science, 37 (1): 81-89. 
Johnson, M.S. and C.J. Veltkamp (1985). Structure and functioning of water-storing agricultural polyacrylamides. Journal of the Science of Food and Agriculture, 36: 789-793.

Klute, A. (1986). Water retention: Methods of soil analysis, part 1. Physical and mineralogical methods. Amer. Soc. Agron. Madison., 9: 635662.

Kumari, S., N.S. Solanki, L.N. Dashora and B. Upadhyay (2017). Effect of super absorbent polymer and plant geometry on growth and productivity of maize (Zea mays L.). Journal of Pharmacognosy and Phytochemistry, 6 (4): 179-181.

Lamm, F.R. and T.P. Trooien (2003). Subsurface drip irrigation for corn production: A review of 10 years of research in Kansas. Irrig. Sci., 22 (3-4): 195-200.

Lamm, F.R. and T.P. Trooien (2005). Dripline depth effects on corn production when crop establishment is nonlimiting. Appl. Eng. Agric., 21 (5): 835-840.

Lamm, F.R, L.R. Stone, L. Harry and M.O. Daniel (2017). Optimum lateral spacing for subsurface drip-irrigated corn. American Society of Agricultural Engeneers, 40 (4): 1021-1027.

Molden, D., H. Murray, R. Sakthivadivel and I. Makin (2003). In "A waterProductivity Framework for Understanding and Action". Water Productivity in Agriculture: Limits and Opportunities for Improvement. (Kijne, J.W., R. Barker and D. Molden Eds.). CABI Publishing and International Water Management Institute, Wallingford, UK/Colombo, Sri Lanka.

Page, A.L, R.H. Miller and D.R. Keeney (1982). In "Methods of Soil Analysis". Second Edition. Madison WI, USA: ASA and SSSA Publisher.

Rafiei, F.G., Nourmohammadi, R. Chokan, A. Kashani and H. Haidari (2013). Investigation of superabsorbent polymer usage on maize under water stress. Global Journal of Medicinal Plant Research, 1: $82-87$

Robiul, I., X. Xue, S. Mao, X. Zhao, A. Egriny and Y. Hu (2011). Superabsorbent polymers (SAP) enhance efficient and eco-friendly production of corn (Zea mays L.) in drought affected areas of northern China. African Journal of Biotechnology, 10 (24): 48874894.

Sarvas, M., P. Pavlenda and E. Takacova (2007). Effect of hydrogel application on survival and growth of pine seedlings in reclamations. Journal of Forestry Science, 53 (5): 204-209.

Shahid, S.A., A.A. Qidwai, F. Anwar, I. Ullak and U. Rashid (2012). Improvement in the water retention characteristics of sandy loam soil using a newly synthesized polyacrylamide. Molecules, 17: 9397-9412.

Egyptian J. Desert Res., 67, No. 2, 291-304 (2017) 
Sivapalan, S. (2006). Some benefits of treating a sandy soil with a crosslinked type polyacrylamide. Aust. J. Exp. Agric., 46: 579-584.

Vories, E., P. Tacker, S. Lancaster and R. Glover (2009). Subsurface drip irrigation of corn in the United States mid-south agricultural water management, 96: 912-916.

Yazdani, F., I. Allahdadii and G.A. Akbari (2007). Impact of superabsorbent polymer on yield and growth analysis of soybean (Glysine max L.) under drought stress condition, 10: 4190-4196. 


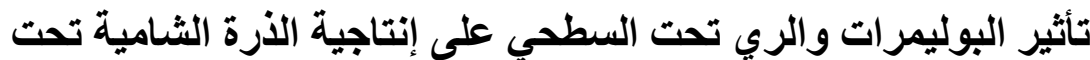

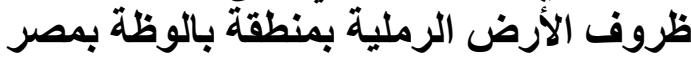

حسام الادين أحمد ثابت شومان

وحدة المحاصيل، قسم الإنتاج النباتي، مركز بحوث الصدحر اء، المطرية، القاهرة

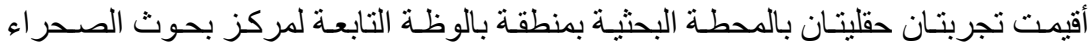

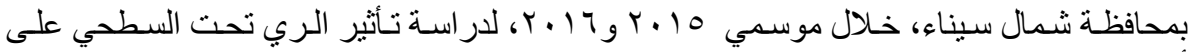

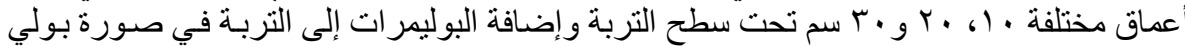

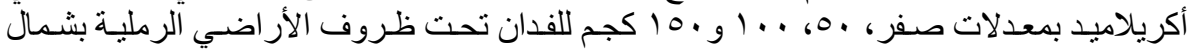

سيناء.

وكانت النتائج المتحصل عليها كالتالي:

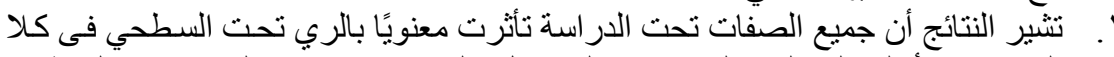

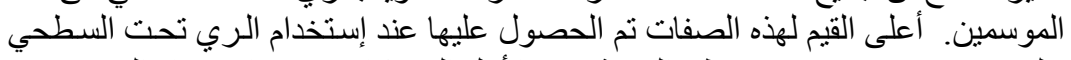

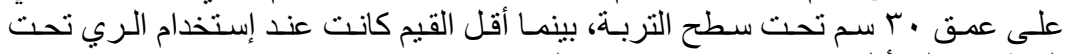

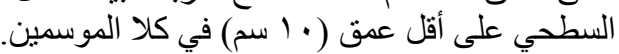

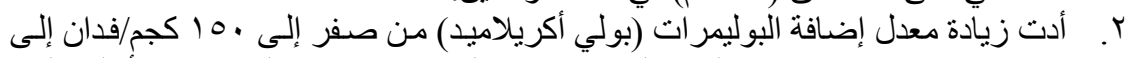

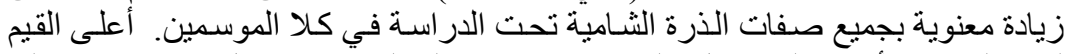

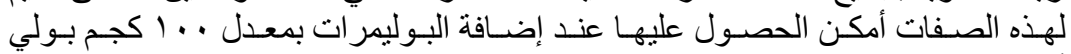

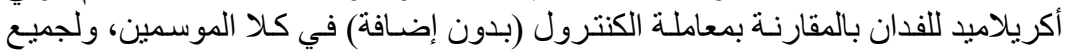

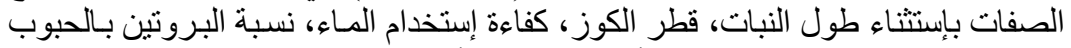

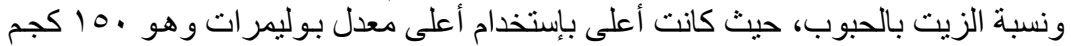

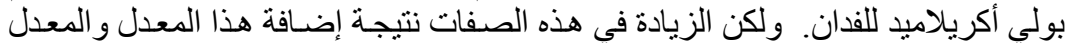

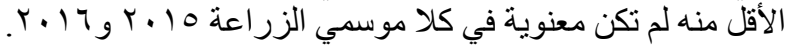

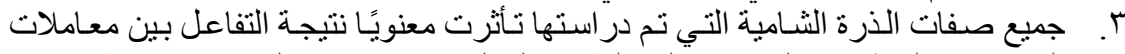

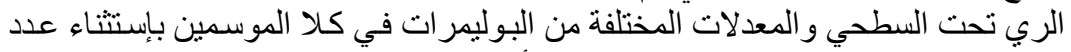

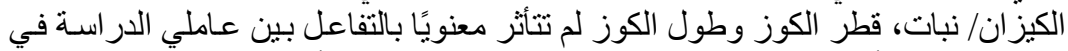

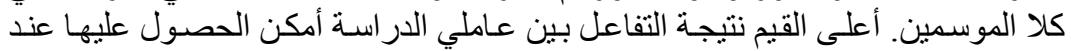

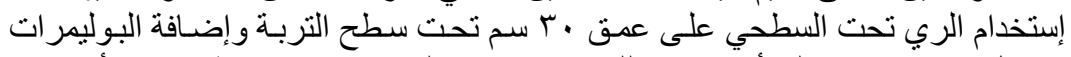

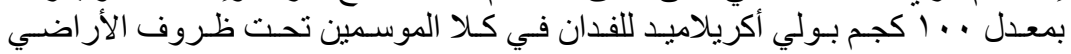

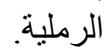

Egyptian J. Desert Res., 67, No. 2, 291-304 (2017) 